\title{
ENTRE RAÍCES: LA DICOTOMÍA CAMPO/CIUDAD, ¿EJE CONFIGURADOR DE UN SUBGÉNERO EN LA NARRATIVA Y EL CINE ACTUALES EN ESPAÑA?
}

\author{
LUIS MARTÍNEZ SERRANO \\ Universidad de Castilla-La Mancha \\ profesor.lmartinez@uclm.es \\ http://dx.doi.org/10.12795/AdMIRA.2017.02.05
}

\section{RESUMEN}

Un pilar de nuestra historia contemporánea se asienta en el fenómeno del éxodo rural acaecido a mediados de la centuria anterior. Muchos escritores y cineastas que lo vivieron han reflejado en sus obras esta experiencia -a veces de forma abierta y a veces más velada- hasta el punto de configurar un subgénero en cine y narrativa dentro del que podemos hallar ya dos generaciones, pues los descendientes de los emigrados están realizando una interesante producción en torno al tema nuclear de la identidad. Nos centraremos en el estudio de la obra de Luis Landero y de Pedro Almodóvar, representativos de lo que hemos denominado la primera generación, para ofrecer algunas de las claves de este peculiar subgénero español articulado en torno a la dicotomía campo/ciudad.

PALABRAS CLAVE: Historia reciente, subgénero, emigración, identidad.

\begin{abstract}
A pillar of our contemporary history is the phenomenon of the rural exodus that happened in the middle of the previous century. Many writers and filmmakers who lived it have reflected in their works this experience - sometimes in an open way and others in a more veiled manner - to the point of setting up a subgenre in film and narrative within which we can already find two generations, because the descendants of the emigrants are making an interesting production around the nuclear issue of the identity. We will focus on the study of the work of Luis Landero and Pedro Almodóvar, representative of what we have called the first generation, to offer some keys to this peculiar Spanish subgenre articulated around the country / city dichotomy.
\end{abstract}


KEYWORDS: Recent history, subgenre, emigration, identity.

\title{
1. Introducción: subgéneros nuevos para nuevas realidades
}

\author{
Invento un género, ... y le doy las leyes que me place.
}

Miguel de Unamuno. Niebla (1914). [1]

Una frase atribuida a Aristóteles afirma que es propio del filósofo recordar a los demás lo evidente. Si tal misión es característica de sabios, no nos avergüenza salvando las distancias- afirmar algo tan obvio como que el autor escribe en una sociedad concreta y para esa sociedad o alguno de sus sectores. La literatura es una manifestación estética, pero también un fenómeno social que trata de explicar cómo esa sociedad se desenvuelve y cómo y por qué cambia. La refleja con sus argumentos, ambientes, opiniones, tensiones entre los personajes, etc. El retrato de la sociedad puede ser real o evasivo y hasta falso; pero en cualquier caso, su presencia, su ausencia o su falsedad dan testimonio de ella. Lo mismo puede afirmarse del resto de manifestaciones creativas, entre las que destaca el cine por ser un constructo que recrea visualmente el momento en que se contextualiza.

Los géneros literarios, artísticos, cinematográficos, son -antes que moldes a los que el creador se deba adecuar- respuestas estéticas a las exigencias que la expresión artística experimenta en un contexto dado. El hecho de amoldarse a los géneros establecidos canónicamente dice mucho del periodo que reflejan: la regla de las tres unidades en el teatro neoclásico europeo es una consecuencia del academicismo y de la sujeción normativa como reflejo del espíritu ilustrado. Por el contrario, el Romanticismo fue rico en mezclar géneros, en usar prosa y verso dentro de la misma obra, en componer poemas de gran polimetría, etc., porque mediante la emancipación creativa se ponía de manifiesto el objetivo ideológico de la libertad.

Algunos géneros literarios responden a unas circunstancias históricas y sociales muy precisas, y sin embargo su esquema ha trascendido. La tragedia y la comedia áticas nacieron como propias de la Atenas del siglo V a. J.C reflejando sus conflictos bélicos, su sistema económico, su religión, su visión del mundo y del ser humano, y la incipiente democracia como marco político. Pero dichas obras, teorizadas por Aristóteles en su 
Poética, han servido de referente cada vez que un autor se ha propuesto componer estos géneros dramáticos, desde Séneca hasta Lorca, pasando por Shakespeare.

En otras coyunturas socioculturales se han originado distintos subgéneros dentro de los clásicos épico, lírico y dramático en literatura, o dentro de los cinematográficos comedia, drama y melodrama. La gesta política y social de la burguesía en el siglo XIX tuvo su épica en la novela realista. El espejo stendhaliano se paseó también por el camino de los desfavorecidos así como por los conflictos internos de los personajes. Dentro de la novela surgió un interesante y novedoso subgénero: un conato de literatura feminista cristalizado en la novela de adulterio, cuyos máximos exponentes fueron Madame Bovary (G. Flaubert, 1857) en Francia, Ana Karenina (L. Tolstoy, 1875) en Rusia, y La Regenta (Leopoldo Alas “Clarín”, 1885) y Laura a la ciutat dels sants (Miquel Llor, 1930) [2] en España. La infidelidad conyugal femenina como intrépido acto de individualidad fue un tema rompedor que no podía dejar incólumes a estas heroínas, castigadas con el suicidio o estigmatizadas de por vida. Aun así, los escritores consiguieron que tal gesto trascendiera como un intento de rebeldía no exento de dignidad.

En la España de comienzos del siglo $\mathrm{XX}$ se gestó un subgénero dramático que escenificó grandiosamente la miseria espiritual del país: el esperpento. Con una estética de la deformación próxima al expresionismo germánico, Valle-Inclán supo radiografiar una sociedad donde se percibía el sinsentido como motor de la política (la pérdida de las últimas colonias, la Guerra de África, la Dictadura de Primo de Rivera...). Este subgénero dramático genuinamente hispano, emparentado en plástica con las Pinturas Negras de Goya, y que remonta sus raíces a las amargas ridiculizaciones de Quevedo, ha trascendido enormemente en literatura y en cine, como es comprobable en filmes de Berlanga, Buñuel o Fernán Gómez, y en algunos aspectos de los comienzos de Almodóvar.

Valle-Inclán puso también, con Tirano Banderas, las bases de un subgénero narrativo de estética esperpéntica: el de la novela de dictador, el cual tuvo una fértil secuela literaria en el cono sur americano con un corpus de narraciones entre las que se hallan verdaderas obras maestras como Señor Presidente (1946) de Miguel Ángel Asturias, Yo, el Supremo (1974) de Augusto 
Roa Bastos, El otoño del patriarca (1975) de García Márquez, o La fiesta del Chivo (2000) de Vargas Llosa.

La dictadura militar azotó esa parte del mundo durante gran parte del siglo XX. Sus testigos hallaron en el modelo valleinclanesco la mejor manera de denunciar la angustia de la opresión, la corrupción política y la anulación del individuo. El ambiente de pesadilla se nutrió de tonos kafkianos y orwelianos; las dislocaciones psicológicas y las secuelas sociales se sirvieron de las nuevas técnicas narrativas exploradas por Faulkner, Dos Passos o Joyce como nuevos cauces de expresión. No es casualidad que muchos de estos autores recibieran el Premio Cervantes e incluso el Nobel de Literatura.

\section{Delimitación del objeto de estudio.}

El cine y la literatura han ido de la mano en el siglo XX. Ambos brotan del manantial común de la narrativa decimonónica, y han ido respondiendo en cada década a las mismas inquietudes sociales y artísticas. El Expresionismo, vanguardia pictórica y cinematográfica, tuvo sus secuelas narrativas. También las corrientes de Realismo Social de los años cincuenta en novela tuvieron su paralelo cinematográfico en El Neorrealismo italiano, así como Le Nouveau Roman francés de los años sesenta se desarrolló en correlación con La Nouvelle Vague de Truffaut o Godard. Nos proponemos hablar de las notas comunes entre cine y literatura dentro del marco de algún subgénero que se haya configurado en nuestros días.

Para ello hemos de partir de la noción de subgénero que realizan García Berrio y Huerta Calvo (1992: 145), quienes parten de los siguientes componentes básicos conceptos básicos de:

- Cauce de representación (la narración, en épica; la actuación, en el género dramático...).

- Género propiamente dicho, definido tanto por la forma como por el tema (la tragedia, el ensayo, la epopeya...).

- Modalidades: de carácter adjetivo, parcial y no a propósito para abarcar la estructura total de una obra (la alegoría, la sátira...).

- Formas: Procedimientos tradicionales de interrelación, ordenación o limitación de la escritura, las convenciones de versificación, la división en capítulos... A veces, como en el caso del soneto, los límites entre género y 
forma son borrosos. Basta añadir una calificación - amoroso, burlesco...- para habérnoslas ante un género plenamente constituido.

Los subgéneros serían el resultado de cruzar algunos cauces de presentación o modalidades con el núcleo genérico como novela paródica o diálogo satírico... Esta definición descansa en una articulación entre constitución formal y contenido temático o ideológico. En los casos vistos anteriormente, partiríamos de la novela como forma épica más un contenido temático reiterado (el adulterio, la dictadura militar) para constituir un subgénero narrativo.

En este sentido, como advierte Kurt Span (1996: 37), se debe proceder con cautela porque "la novela o el cuento admiten todos los temas imaginables". Este autor defiende la variable de un criterio histórico y sociológico - "en el sentido de una convención artística en el tiempo" (1996: 37)- como fundamento de "su ser como género". En este criterio nos hemos basado para elegir los ejemplos puestos más arriba, y la elección de nuestro objeto de estudio: ¿se puede hablar de algún tema y su molde expresivo como característicos de nuestra época, entendiendo por tal la segunda mitad del siglo XX y lo que va del nuevo siglo, en el contexto español? ¿En la España contemporánea se ha producido algún género o subgénero literario, cinematográfico... que la identifique, y que, con la pátina del tiempo, sirva para diseccionarla? Algunos autores hablan del cine y la literatura por décadas o por el signo político del momento como condicionante (Juan Payán, 1993; Caparrós Lera, 2005). Pero esto sería sólo un contexto sociopolítico, no hay una materia y una estética aglutinantes.

Si partimos de que los rasgos definitorios de un subgénero son en principio formales (partimos de un género definido, en este caso el narrativo) mediante el que se da forma a un tema recurrente, dentro de unas circunstancias histórico-sociales que moldean en unas determinadas formas de expresión, tanto en novela como en cine, creemos que se puede hablar de un tema muy arraigado: una preocupación constante por la identidad, que se remonta a planteamientos unamunianos o pirandellescos, y que hoy adquiere un especial tratamiento en la cuestión de la dicotomía campo/ciudad. 


\section{Metodología.}

Haremos un repaso de algunas afirmaciones del novelista Luis Landero y del director Pedro Almodóvar, y realizaremos incursiones en sus respectivas obras, por considerar a ambos creadores paradigmas de una generación cuya nota común es haber vivido el éxodo rural durante la infancia, lo que entendemos ha dado lugar a un vernáculo subgénero, y no sólo por ser un tema recurrente, sino por forma la especial de tratarlo. Nuestro método será por tanto un análisis cualitativo de un discurso narrativo y otro audiovisual de forma comparada.

La razón de este análisis simultáneo de dos discursos se basa en el deseo de mostrar las concomitancias entre ambos. No sólo de tipo temático, también para exponer la repetición paralela de algunos constituyentes que entendemos que son fruto de similares circunstancias histórico-sociale. Queremos con ello considerar la narración literaria y la cinematográfica como dos caras de una misma moneda, dos formas de expresión que responden a estímulos y a condicionantes parecidos.

Por otro lado, el presente trabajo se fundamente en un estudio anterior de la dicotomía campo/ciudad en la narrativa de Luis Landero (Martínez Serrano, 2013: 99114). Hemos retomado aspectos relevantes para el presente análisis, y hemos intercalado entre ellos las partes de la obra de Pedro Almodóvar que poseen rasgos semejantes, profundizando más en esta, por estar la de Landero ya estudiada en detalle en la mencionada publicación, aunque en este estudio aportaremos algunas ideas nuevas. De esta forma, elementos hallados en el estudio de Landero actúan como eje desde cuyos puntos hemos ido analizando parte la obra almodovariana.

\section{Revisión bibliográfica.}

El estudio del espacio de la infancia rural como configurador de peculiares ambientaciones, personajes y temas ha sido estudiado en el volumen Lugares de ficción. La construcción del espacio en la narrativa actual (María Pilar Celma y José Ramón González: 2010), donde, desde una perspectiva general, se abordan algunos de los desarrollos teóricos y conceptuales sobre la relevancia de la dicotomía campo/ciudad en la construcción de espacios de ficción. Recoge varios ejemplos de análisis en los que se pone de manifiesto la rentabilidad crítica de las nociones espaciales - en concreto el paisaje y la naturaleza como espacios de la infancia - aplicadas a la lectura de un amplio 
corpus de relatos publicados en los últimos treinta años cuyos autores poseen algún vínculo rural.

Además del mencionado estudio sobre Luis Landero (2013), el tema de la dicotomía campo/ciudad como configurador de parte de la literatura y el cine contemporáneos en España (planteado como un componente muy presente en ambos) ha sido estudiado por Sergio del Molino en La España vacía (2016) desde un enfoque sociológico. En este ensayo el autor reflexiona sobre la necesidad de tener en cuenta la emigración del campo a la ciudad que tuvo lugar en las décadas de los años 50 y 60 en España como clave de gran parte de la narrativa y el cine actuales. Pero sobre todo es una aproximación, desde un punto de vista humanístico, un tema tan lábil y difícil de abordar como el de la identidad, cuyo componente principal intenta explicar a partir de la experiencia del éxodo rural. Los autores que la vivieron han usado el cine y la literatura como vías de expresión para verbalizar su forma de estar en el mundo y de comunicarse, constituyéndose sus obras en desquites vitales a través de la imaginación.

Para nuestro estudio, en primer lugar partiremos de un anuncio publicitario que apelaba a los "urbanitas sin pueblo" para poner de manifiesto la existencia de grupos de población en las ciudades cuyo origen se cifra en la emigración rural de mediados del siglo XX. Hablaremos de dos generaciones de escritores y cineastas que han recurrido a este tema de forma asidua, considerando algunas notas comunes en sus producciones, y centraremos nuestro estudio en un análisis comparativo entre algunas partes de la obra de Luis Landero y de Pedro Almodóvar, considerándolas dos ramas narrativas de un mismo tronco común histórico-social, profundizando más en la del director manchego por las razones expuestas más arriba. Por último, realizaremos una serie de conclusiones sobre si podemos hablar de un subgénero narrativo o se trata de un tema recurrente.

\section{Planteamiento}

Un indicador de la presencia en el imaginario colectivo de la dicotomía que da título a este trabajo lo constituye la estrategia del anuncio de Aquarius del año 2012, que proponía al espectador la posibilidad de ser 
adoptado por un pueblo [3]. Es sabido que el modus operandi de las grandes marcas consiste en ofrecer una información arraigada en algún punto sensible del receptor, quien impactado emocionalmente puede ser inoculado con cualquier producto. ¿El inconsciente de quiénes trataba de remover el anuncio de Aquarius poniéndoles ese espejo delante? No era gratuito que se dirigiera a "los urbanitas sin pueblo", debía de ser un grupo relevante cuando la marca lo estaba intentando captar.

Creemos que en lo que planteaba esta publicidad existe un profundo calado en cuya prospección hallamos parte de nuestra historia reciente. Nos referimos a las bolsas de población cuyo origen se sitúa en la emigración del campo a la ciudad que tuvo lugar a finales de los cincuenta y sobre todo en los sesenta, cúmulos de gente campesina que llegaron a constituir un notorio pero difuso grupo en las grandes ciudades. Personas en su mayoría marcadas por lo que Sergio del Molino (2016: 28) llama El Gran Trauma, ya que “... el país se urbanizó en un instante. En menos de veinte años, las ciudades duplicaron y triplicaron su tamaño, mientras vastísimas extensiones del interior se terminaron de vaciar y entraron en lo que los geógrafos llaman el ciclo del declive rural. Entre 1950 y 1970 se produjo el éxodo".

1. Variación de la población española 1950-1981.

Si miramos el mapa anexo, vemos que en 1981 el 15,6 \% de la población vivía en algo más de la mitad del territorio (el 53\%). La situación ha variado poco, a día de hoy más del $84 \%$ de los españoles viven apretados en el $48 \%$ del territorio [4]. Este desequilibrio se produjo en pocos años, lo que redundó en un choque cultural muy brusco que ha tardó años en desvanecerse. Una película tan emblemática como La ciudad no es para mí (Pedro Lazaga, 1966) recogía, en su relato reaccionario, un recelo marcado hacia la gran urbe en un discurso ideológico claramente conservador, desde un enfoque que traducía ciertas inquietudes en estas franjas de población que se tenían que enfrentar a evoluciones sociales y políticas a las que temían.

El dato de la desigual distribución de

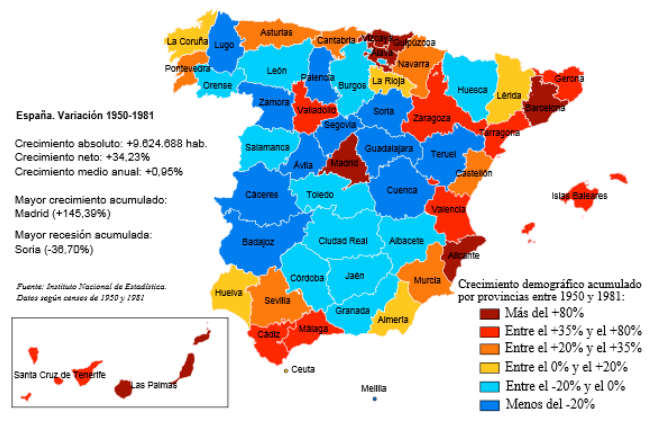
población entre las zonas rurales y las urbanas en España la convierte en una peculiaridad demográfica en Europa. Italia mide 301.000336 kilómetros cuadrados, lo que supone unos tres quintos de España, pero en esa extensión viven 61 millones de personas (un 30\% más que aquí). Todo el Reino Unido equivale a menos de la mitad de 
España, y en él viven 63,5 millones de personas, un 35.9\% más. En Alemania, en una superficie que representa un $70,8 \%$ de la española, viven 82,7 millones de habitantes, es decir, 36 millones de personas más en un territorio casi un tercio menos que el de España. Europa occidental no solo está muy poblada, sino que sus habitantes se reparten con uniformidad notable. Viajar en coche por Inglaterra o Francia consiste en una sucesión de pueblos y viviendas ininterrumpida (Del Molino, 2016: 41). El dato oficial de la densidad española fijada en 93 habitantes por kilómetro cuadrado en 2016, no refleja la realidad demográfica, nada tiene que ver Madrid (con ochocientos habitantes por kilómetro cuadrado) con Teruel (nueve habitantes por kilómetro cuadrado). Esta disparidad supone pasar, en poco espacio, de zonas de densidades medias y altas a regiones técnicamente desérticas. Se trata de un desequilibrio añejo y estructural, particular de España, cuyas razones no es lugar éste para averiguar, pero cuyo último movimiento de vaciamiento hacia zonas más populosas ha tenido lugar durante las dos décadas señaladas de la centuria anterior, momento en que nos queremos situar como contexto clave.

Lo protagonizaron grupos que sufrieron cierta marginalidad y hasta se sintieron víctimas de un velado engaño cuando se vieron hacinados en grandes bloques construidos por el régimen franquista, el cual se vanagloriaba de dichas aglomeraciones como un logro social. Así, al desarraigo se sumó la desilusión cuando la ciudad no respondía al sueño americano que se habían forjado [5].

Las ideas estereotipadas que rezuma el reclamo publicitario de Aquarius hacen referencia a la imagen bucólica que del campo se tiene desde la ciudad; y, a modo de contrapunto, al aislamiento y el anonimato como constituyentes de soledad en la urbe. Pero el tema clave que nos desarma en última instancia es el de la identidad. Esta dicotomía entre el origen rural, el traslado a la ciudad, y la instalación que nunca echa raíces ni fragua en una naturaleza urbana para los emigrantes, constituye -a nuestro parecer- una herramienta hermenéutica que nos permite desmontar algunas constantes de la literatura y el cine actuales. Luis Landero ha manifestado en numerosas ocasiones, y ha desglosado por extenso en Esta es mi tierra [6] que el traslado desde su pueblo, Alburquerque, a Madrid en 1960 supuso un antes y un después en su vida, pero sobre todo uno de los demonios personales cuyo exorcismo ha sido el oficio de escribir. 
Asimismo afirma (Landero, 2002: 226) que "un escritor debe saber cuál es su mundo, cuáles son sus demonios y ser fiel a ellos [...], debe escribir sobre aquello que conecta con sus inquietudes y experiencias más íntimas. [...] lo que formuló Camus de un modo más directo: Cada escritor debe saber de dónde mana su manantial". Reflexión nuclear para nuestro propósito: consideramos que el venero del que brota parte del hontanar creativo de un grupo de cineastas y escritores de nuestros días hay que buscarlo en su pasado rural.

Podemos distinguir dos grupos entre ellos, correspondientes a dos generaciones, con inquietudes distintas dentro de una misma tendencia. El primero lo constituiría la generación de quienes vivieron la experiencia del abandono del hogar familiar, cuya obra ha sido una busca del tiempo perdido. Entre ellos cabe citar a Luis Mateo Díez nacido en Villablino, (León) en 1942. En Memorial de hierbas (1973) se halla el relato La familia de Villar, donde un niño vive el exilio de la tierra donde nació, ahora anegada por las aguas de un pantano, las mismas que, canalizadas, servirán a su padre para regar sus cultivos en suelo extraño. En Camí de sirga (1988) Jesús Moncada levanta una cosmogonía alrededor de Mequinenza, en la franja oriental de Aragón, "tierra de emigrantes y silencios" (Del Molino, 2016: 77). Antonio Muñoz Molina indagó en sus orígenes rurales en la provincia de Jaén en El jinete polaco (1991). Julio Llamazares retrató el drama de los pueblos abandonados en La lluvia amarilla (1988), y da una vuelta de tuerca al tema en su último libro Distintas formas de mirar el agua (2015), donde narra la forzada marcha de una familia de su pueblo por la construcción de una presa, situación que el propio novelista experimentó en tierras de su León natal.

El pantano que anega la tierra atávica es una metáfora sobre la imposibilidad de recuperar la infancia perdida, un espacio vital despojado a la fuerza con el que se intenta enlazar mediante la literatura. En dicha recreación existe una defensa, y una idealización, del pueblo como reducto de valores perdidos.

Si se puede hablar de algún magisterio sobre el grupo éste correspondería a Miguel Delibes -perteneciente a una generación anterior- y sus narraciones de ambiente rural, cuya novela emblemática sobre un mundo que resiste sería El disputado voto del Señor Cayo (1978), llevada al cine en 1986 por Antonio Giménez Rico. El eminente escritor vallisoletano tituló su discurso de entrada en la RAE Un mundo que agoniza (1979), publicado luego en forma de ensayo.

En cine, encontramos las mismas claves en el filme El cielo gira (2004) de Mercedes Álvarez, tras cuya emisión en el programa Versión española tuvo lugar un 
debate en el que participaron Miguel Marías, Julio Llamazares y la propia directora [7], la cual manifestó haber vivido la separación de su tierra -el páramo soriano- durante la infancia como un desgarro vital, sentimiento que pretendía reparar con la película. Otros largometrajes donde se identifican la pérdida de ciertos valores con la infancia irrecuperable son Tasio (1985), de Montxo Armendáriz y La lengua de las mariposas (1999) de Jose Luis Cuerda.

El segundo grupo se correspondería con los descendientes de la generación que emigró del campo. Así, la tierra abandonada no sólo persiste en quienes la vivieron, sino también en sus hijos y nietos, quienes crecieron empapándose de esa nostalgia. Sus libros ponen de manifiesto que el país puede arrojar estadísticas sobre el crecimiento de la población urbana en dos décadas, pero las personas necesitan varias generaciones para adaptarse a las ciudades a las que se mudaron.

Por ejemplo, Francesc Serés (1972) cuenta en La pell de la frontera (2014) cómo el vacío del éxodo rural se ha llenado con el de la inmigración de rumanos, marroquíes y ecuatorianos. Jorge Carrión narró en Crónica de viaje (2014) su reencuentro con sus orígenes alpujarreños y andaluces. Manuel Astur compone su particular menosprecio de la corte y alabanza de la aldea en Seré un anciano triste en un gran país (2015) reivindicando una vuelta a la sencillez de lo primordial en una fuga de la ciudad hacia el interior de uno mismo. En cine, la gran película sobre la generación que se identifica con los ancestros es El olivo (2015) de Icíar Bollaín.

Nos vamos a centrar en el estudio comparativo de dos miembros de lo que hemos denominado la primera generación. Dejamos el segundo grupo generacional para ulteriores estudios. Hablaremos ahora de Luis Landero (Alburquerque, 1948), en narrativa, y de Pedro Almodóvar (Calzada de Calatrava, 1949) en cine. Deseamos demostrar cómo gran parte de sendas obras ha de ser enfocada desde el ángulo de los orígenes rurales para ser entendida plenamente, y veremos en ellos notas comunes cuyo origen es la experiencia del viaje hacia la urbe durante la infancia. 


\section{Análisis comparado de la experiencia fundacional del traslado a la ciudad} en Luis Landero y en Pedro Almodóvar

Y tú, que antes no sabías si tu familia o tú mismo erais del campo o del pueblo, ahora tampoco tienes claro si perteneces al pueblo o a la capital. Pero la imaginación, con sus mentiras tan necesarias y sinceras, viene a anudar los hilos sueltos de una realidad fragmentaria y caótica. (Luis Landero, 2014: 77).

La principal nota común de este viaje es que sus protagonistas lo vivieron como un desplazamiento en el espacio y en el tiempo: "De Alburquerque a Madrid hay unos cuatrocientos kilómetros. El viaje duraba entonces unas doce horas. Pero ese tiempo era engañoso, porque en realidad aquel era un viaje hacia el futuro. Uno salía del siglo XIX y, doce horas después, se encontraba de pronto en el siglo XX" (Landero, 2001: 53-54). "Para mí, Cáceres en los años sesenta era como París en los años setenta", relató Pedro Almodóvar a Boquerini (Blanco, 1989: 14).

También comparten la imagen idealizada que desde el mundo rural se tenía de Madrid transmitida por los progenitores. En el caso de Luis Landero fue su padre: "Madrid era sencillamente irreal, un espacio poco menos que sagrado para nosotros. Con ocho años, mi padre, haciendo un gran esfuerzo económico, me mandó interno a un colegio de Madrid. Era lo máximo que podía hacer por mí. Era mandarme a la gran Metrópoli, a la gran ciudad redentora, donde yo, según sus cuentas, debía convertirme en un gran hombre" (Landero, en Rey Hazas, 2004: 101). En el de Pedro Almodóvar la madre es la artífice de esta idealización: "Mi madre me transmitió la imagen de un Madrid legendario y yo me lo imaginaba como una de esas ilustraciones de las enciclopedias que tanto me gustaban. Creí que vivir en Madrid era algo así como vivir en los decorados de la emperatriz Sisí'. (Camarero, 2016: 1).

El padre del cineasta fue el último de una larga línea de arrieros que llevaban pellejos de vino desde una bodega, propiedad de la familia en Calzada de Calatrava, hasta el norte de la provincia de Jaén, a unos cincuenta kilómetros, donde las minas de plomo y de plata de El Centenillo, pedanía de Baños de la Encina.

En 1953 concluye la explotación minera. Terminado a la fuerza el acarreo de vino, la familia se traslada a Extremadura, atraída por las promesas de trabajo que ofrece el Plan Badajoz. Ambos, Luis Landero y Pedro Almodóvar, tienen solo ocho años cuando dejan el pueblo, pero reivindicarán su identidad rural el resto de su vida. 
Sus orígenes y sus años provincianos saldrán a relucir continuamente: "Mis referencias son provincianas, y yo, lejos de negarlas, las desarrollo [...] porque una ciudad como Madrid está compuesta de toda esa gente que viene de los distintos pueblos de España"(Vidal, 1988: 87).

La familia Almodóvar se instala en Orellana La Vieja y después en Madrigalejos. Desde Cáceres, donde ha estudiado con los salesianos, el futuro cineasta se traslada a Madrid en 1967. Por otro lado, toda la familia de Luis Landero se va a Madrid en 1960, en un viaje en tren que marcará al escritor.

Ambos emprenden una búsqueda de sí mismos absorbiendo cuanto les rodea. Luis Landero aprende a tocar la guitarra y se enrola en un grupo de flamenco que actúa de vez en cuando en el extranjero. El escritor conoce lugares legendarios para él, como Japón. Almodóvar se traslada a París y a Londres, donde acaricia la idea de instalarse, pero regresa a España. Lo contratan como figurante en películas en que necesitan grupos de hippies (pues se ha dejado el pelo largo). Vende joyas flower power en la calle, visita Ibiza... Colabora en películas como Qué hace una chica como tú en un sitio como éste (F. Colomo, 1978) o Un hombre llamado flor de otoño (P. Olea, 1978). Participa en el grupo de teatro independiente Los Goliardos donde conoce a Félix Rotaeta y a Carmen Maura, personas claves en su primer largometraje.

Ambos artistas van pergeñando en estos años sus temas axiales. Dichas experiencias acabaron convirtiéndose en hechos fundacionales donde, junto a sus recuerdos rurales, situamos sus hontanares creativos. Del paso por el mundo de la farándula saldrá la novela de Landero El guitarrista (2002). Pero lo que más le inspira es la atracción que su padre sintió por la ciudad y el progreso, el tema del afán, que será el principal resorte de Juegos de la edad tardía (1988), Hoy, Júpiter (2007) y El balcón en invierno (2014).

En Almodóvar, el componente rural es manifiesto en un grupo de películas cuyo colofón sería Volver (2006). De la profesión de su padre procede la escena de ¡Átame! (1990) en la que Marina (Victoria Abril) aconseja al propietario de una mula, llamada Rosita, cómo curarle al animal una afección en la pezuña. En Orellana La Vieja tiene lugar el episodio de las lecturas de las cartas a las vecinas por parte de la madre embelleciéndolas conforme a las esperanzas de los destinatarios, relatada por Marisa Paredes en La flor de mi secreto (1995). Almodóvar comparará este recuerdo medular de su poética con 
Estación Central de Brasil (1998) de Walter Salles, y explicará en textos y entrevistas que dicha experiencia le mostró cómo la realidad necesita la ficción para ser más soportable. De su paso por los salesianos saldrá La mala educación (2004) amén de otras escenas que son variaciones sobre un mismo tema, como la canción de Yolanda en Entre tinieblas (1983) o la canción que entona Tina en La ley del deseo (1987) mientras se aproxima a su antiguo director espiritual.

Luis Landero nos cuenta en Esta es mi tierra (2002: 69-70):

Deduje yo que las cosas maravillosas pasaban siempre en sitios distantes y en edades remotas, y que en Alburquerque (es decir, aquí y ahora) nada prodigioso podía ocurrir nunca. Pero luego, cuando emigramos a Madrid y pasaron los años, supe que era entonces, en la infancia, cuando vivía realmente en un país lejano, lleno de prodigios, sólo que yo no lo supe ver hasta que la memoria me devolvió aquellos recuerdos convertidos ya en poesía por la nostalgia.

Pedro Almodóvar siempre ha manifestado consideraciones muy parecidas. No es difícil imaginarlo, niño silencioso y por ello buen escuchador, impregnándose de esas tertulias de pueblo en que la gente humilde saca las sillas las calles, y en la acera, a la puerta de la casa, en la noche manchega. Del paradigma de abuela manchega que encarna Chus Lampreave dice Almodóvar: "Lo he sacado de mi madre y de sus vecinas, de sus conversaciones y de su espíritu; es un compendio de frases y de mentalidad que yo he visto en mi madre" [8]. Landero (2002: 65) confiesa por su parte que "De los narradores que yo conocí, quien mejor contaba las historias era mi abuela Francisca, que era analfabeta pero tenía una gran sabiduría para el relato oral”. Otra feliz coincidencia, el nombre propio de la persona que más influyó en sendas formas de relatar.

En cuanto a la forma, no se puede olvidar la capacidad renovadora del discurso fílmico de Almodóvar, tan lejos de Surcos (Nieves Conde, 1951) o de Los santos inocentes (Mario Camus, 1984). Su magisterio se asienta en el nuevo enfoque superador del costumbrismo para ofrecer una visión iconoclasta y a veces corrosiva. La "modernidad postmoderna" de Pedro Almodóvar pasa por numerosos canales creativos entre los cuales la geografía viene a ser uno de los más renovadores y complejos, entendiendo por esta geografía un lugar intermedio en el que tienen cabida tanto "el campo como la ciudad, lo horizontal y lo vertical, en constante interrelación dialéctica, y elaborando un espacio específico. A partir de esta síntesis van emergiendo algunos aspectos del espacio almodovariano" (Seguin, 2005: 229). 
En la presentación del cineasta que realizan los medios de comunicación, la alusión a su lugar de nacimiento parece inevitable; sin embargo, cuando se observan entrevistas a cualquier otro director al periodista en absoluto le importa informar que Gutiérrez Aragón, por ejemplo, es cántabro. Es un hecho que conoce todo espectador español (y gran parte del público extranjero) que Pedro Almodóvar es manchego, pero seguramente ignora dónde nacieron Mario Camus, Carlos Saura o Juan Antonio Bayona. ¿Qué subyace a tanta insistencia sobre el mancheguismo de Almodóvar? ¿Qué se nos quiere dar a entender bajo tanta apelación a los orígenes?

Quizá el hecho de haber crecido en una moral de represión y austeridad y haber apostatado completamente de ella hasta conseguir representar la libertad, la vanguardia, la moda, el diseño... y sobre todo el disfrute. Su obra es un gran carpe diem. Esto no ha sucedido sin experimentar personalmente la confrontación entre mundos antagónicos. Cuando el programa de La Sexta Todo cine preguntó al director en 2011 por su escena favorita, Almodóvar eligió una de Esplendor en la hierba (Elia Kazan, 1961) con la que decía identificarse la primera vez que la vio por hablar de "un mundo de provincianos [...]. Yo pensaba que estaban hablando de mí, de La Mancha y de Extremadura" [9]. Algo similar había experimentado con Antonioni: "Cuando vi La aventura (1960), quedé trastornado. Pensé «Dios mío, esta película habla de mi vida» [...]. La película hablaba del aburrimiento y eso sí sabía lo que era allá en Extremadura" (Correa Ulloa, 2008: 15).

El Pedro Almodóvar rico y famoso mantiene ciertos resabios que explota como excentricidades kistch: "Colecciono bolsas de plástico, y en eso soy como mi madre, que ve una y dice: «Qué bolsa tan hermosa»" [10]. Nos atrevemos a asegurar que aquí se asienta el origen de la expresión de la abuela Blasa en ¿Qué he hecho yo para merecer esto? (1984): "Me gustan las bebidas con gas, el cementerio, las bolsas de plástico... y el dinero". Jacinta, en La flor de mi secreto (1995), papel interpretado de nuevo por Chus Lampreave, entrega a su hija Leo un tarro que va envolviendo con una bolsa de plástico a la vez que le dice "te he asao unos pimientos..."; el envoltorio es para ella un primoroso papel de regalo. Agustina, en Volver (2006), guarda los objetos personales de su desparecida madre y presume de que son de "plástico del bueno" ante la joven Paula, quien los toca con admiración. 
Pedro Almodóvar, que ya ha sobrepasado el medio social de origen y lo ha trascendido en arte, ha aprendido a amarlo en la distancia. Se encuentra incómodo, raro, cuando vuelve a la realidad manchega que para él ya no es la vida real, sino un background artístico-vital. "Viniendo aquí me siento más cortado que en cualquiera de mis otros viajes. [...] Es muy difícil enfrentarse a tus raíces...” (García de León y Maldonado: 1989, 34).

La presencia de lo rústico es algo implícito que se halla modelando historias y personajes con un particular código genético. El pueblo empezó siendo sólo mencionado como un regreso al origen con tintes redentores. En sus tres películas más rurales se produce una especie de progresión en la aparición y el protagonismo que va tomando el mundo manchego: ¿Qué he hecho yo para merecer esto? (1984), La flor de mi secreto (1995) y Volver (2006). Siempre en relación con la figura de la madre. En la primera, esta nota la pone la propia Dña. Francisca interpretando un papel. En la segunda, la madre salva de la muerte a su hija Leo con su voz y se produce un renacimiento de la protagonista tras un viaje al lugar de la infancia contado como un regreso al claustro materno. En la tercera, la vuelta al pueblo se plantea como una catábasis, un descenso a los infiernos -como Orfeo o Dante- para recuperar a la madre perdida.

Julieta sería el epílogo de la trilogía rural, un intento fallido de enlazar con las raíces. Fallido porque ya no hay comunicación posible con la madre (por culpa de la enfermedad) ni conexión con el padre, por la diferencia de puntos de vista. Desaparecida la madre, Julieta se desmarca del pasado y del resto de su familia. El pueblo como background artístico está liquidado por el momento.

¿Qué he hecho yo para merecer esto? ofrece la desilusión que la ciudad que ha supuesto para quienes han depositado sus esperanzas en ella como solución de los problemas socioeconómicos, pero sobre todo muestra la inadaptación de la abuela. Los paraísos perdidos poseen asentamientos contrapuestos: la ciudad pasa de ser centro de la ambición afanosa para ceder el rumbo de los sueños al campo, en alusión a Esplendor en la hierba, a cuya proyección han asistido la abuela y el nieto. Este intertexto fílmico desplegará su justificación diegética en el desenlace de la película.

La cambiante metrópoli desconcierta a la anciana, que no le encuentra sentido más que algunos pequeños placeres que no posee en el pueblo: el juego (aficionada a las máquinas tragaperras) o el cine, siempre acompañada de Toni, quien ejerce de lazarillo por este intrincado espacio en el que ella se siente como en un laberinto. No entiende a 
la gente de su alrededor, por eso se refugia en el nieto, y cuando su hijo muere se siente más perdida e incluso absurda en ese lugar al que precisamente su hijo la había traído.

En La flor de mi secreto la necesidad de renovarse se hace patente. Nunca antes el pueblo había sido mostrado. En su día el director declaró que era su película más manchega. Sin embargo, Leo regresará a Madrid, porque el pueblo no puede constituir una solución. Ocupa una función vital, es una máscara de oxígeno para poder ir de nuevo hacia delante. A la tierra se regresa para un fin muy preciso, como hizo Pedro Almodóvar al ofrecer su segundo óscar al lugar que lo vio nacer. Puede ser una recuperación momentánea para saldar deudas, como sucede en Volver. En el pueblo el cuerpo se alimenta y encuentra fuerzas perdidas, se reconcilia con uno mismo para llevar a cabo el verdadero proyecto.

También es el lugar de la despedida que cierra el círculo vital. Alfredo, el protagonista de El amante menguante, (Hable con ella, 2002) vuelve con su madre ante la adversidad de su trastorno. Ricky (Átame, 1990) regresa a Granadilla para reorientarse contactando con la infancia arrebatada y sepultada bajo un pantano, como en los relatos de Mateo Diez y Julio Llamazares. También Lola/Esteban (Todo sobre mi madre, 1999) visita por última vez su pueblo en Argentina cuando se siente en la recta final. Regresar al punto de partida para morir en él es lo que hace Becky del Páramo (Tacones lejanos, 1991) retornando a la portería de sus padres. Estos regresos vitales poseen su origen en la experiencia del padre del cineasta, D. Antonio Almodóvar, quien pidió volver a su casa natal para fallecer:

Mi padre murió de cáncer... Mi familia vivía en Extremadura y mi padre, cuando ya se sintió en las últimas, le dijo a mi madre que lo llevara al pueblo donde había nacido. [...] Desde el momento en que llegó, duró como unas diez horas, todos los dolores le desaparecieron, y murió en la misma cama donde había nacido. Estos recuerdos son los que contiene esa parte de la vida de Marisa en Tacones lejanos (Strauss, 1995: 68).

La muerte del padre también opera en Landero como un leit motiv “... es el episodio central de mi vida, y el manantial de donde brota ciego en incontenible mi destino" (Landero, 2014: 88). 
La presencia del mundo rural es algo proteico y tácito que se manifiesta de variadas maneras. En primer lugar, mediante solares por donde el campo parece querer recuperar su papel perdido. Una característica de los entornos geográficos de ¿Qué he hecho yo para merecer esto? es la inconclusión: los edificios surgen en medio de descampados, en tierras de nadie como si la ciudad desvelara sus orígenes como primer asentamiento. También la penetración en la ciudad condal (Todo sobre mi madre) se produce por zonas indeterminadas, por esos campos de abandono que fusionan lo rústico con lo urbano. En segundo lugar, mediante manifestaciones del modo de vida rural en la casa urbana: comida, organización de espacios, decoración, objetos de devoción, altares... Y de forma más asidua, en tercer lugar, por los afloramientos etnográficos en forma de expresiones orales o hábitos: "lo escondes todo como una urraca", o "una operación es un melón cerrao: hasta que no lo abres no sabes si está bueno, o está pasao...”. El hecho de invocar a Santa Bárbara durante una tormenta o rezarle a San Antonio para que encuentre algún objeto perdido denuncia una religiosidad de tipo campestre, temerosa de la naturaleza y protectora de los escasos bienes en propiedad.

En todos estos casos sucede como si un mundo paralelo se filtrase por algún resquicio de la envoltura urbana, como si una fuerte presencia latente pugnara por salir. "En ¿Qué he hecho yo...? hay una clara demostración de cuáles son mis orígenes. Yo soy una persona muy urbana, pero mi familia tiene un origen como el de ¿Qué he hecho yo...? Hacer esta película era un testimonio emocionante y a la vez ético" (Vidal, 1988: 90). El resultado es la yuxtaposición de elementos de ambos mundos conformando un entramado postmodernista de retazos de diverso origen en el que el componente rural está en segundo plano, solapado, difuso... como esas bolsas de población que mencionábamos al principio. Piénsese en la sofisticada Mujeres al borde de un ataque de nervios (1987) con sus áticos, sus modelos, sus taxis exóticos, y Candela (María Barranco) dando de comer a los conejos en un corral en la terraza; en las morcillas de Matador (1986) o en la exhortación “¡Cómase un chorizo, que los hago yo!” que Doña Francisca espeta a un escritor de novela negra en Kika (1993).

A medio camino entre la ciudad y el campo se halla la periferia. En Almodóvar responde a una doble tensión: una fuerza centrípeta que tiende a recoger el relato hacia un centro siempre inasequible -meta ilusoria concebida como parangón de la modernidad-, y por otra parte una fuerza centrífuga que hace que los personajes siempre sientan el deseo de alejarse de la ciudad. El más allá, el afuera, el extrarradio... elaboran 
un polo bastante borroso que va imantando a un número cada vez más grande de personajes. El sistema narrativo de las películas implica ese ir y venir, esa necesidad de alejarse para volver, como un boomerang, dejando claro que la periferia nunca viene a constituir una solución.

Un elemento clave de la filmografía almodovariana, casi un estilema, es el tratamiento de las viviendas. La casa del pueblo pone en tela de juicio continuamente la preeminencia de la ciudad, pues se insinúa y agazapa en ventanas y balcones con geranios, en terrazas con corrales, y sobre todo en las cocinas, piezas corpóreamente transitorias entre la huerta y el frigorífico. Las cocinas de Pedro Almodóvar rebosan de legumbres, de chorizos manchegos, de morcillas, de bacalao al pil pil, de aceite Carbonel, de pastas, de flanes, de frutas y de un sinfín de ingredientes que se funden, metafóricamente, en un gazpacho metonímico. Pocos directores han concedido tanta importancia a las cocinas convirtiéndolas en microcosmos de resistencia (Seguin, 2009: 59-68).

La casa es también un elemento clave en el imaginario de Luis Landero: “Al principio el mundo era para mí la casa de mis padres [...]. En ese breve microcosmos yo conocí en mis primeros años casi todo cuanto hay que conocer en la vida [...]. Aquí sitúo yo en mi mente la acción de muchas novelas y dramas. Por sus alcobas y corredores han transitado Oliver Twist, Pascual Duarte, Aureliano Buendía..., y muchos más" (2002: 61-63). La casa se convierte en un elemento reelaborado estéticamente que enlaza el mundo literario con los orígenes, convirtiéndola en un lugar de confluencia de recuerdos con aspectos creativos. El tratamiento de microcosmos nuclear, espacio de la creatividad, contrasta con el tratamiento de la casa urbana, presentada como un símbolo kitsch de la alienación en la que vive el emigrado, sublimación de la comodidad y el bienestar burgueses:

“A los emigrantes que en España llegaron a las grandes ciudades hacia 1960 les ocurrió otro tanto que a los indios cuando los conquistadores arribaron a sus tierras, y así, recibieron los abalorios, espejitos y cascabeles correspondientes a la época industrial: un piso en el suburbio, algunos electrodomésticos, mesitas bajas de cristas, un pequeño automóvil los más afortunados, televisor, enciclopedia universal en fascículos; algunos cuadros de caballos ingleses y caza del ciervo con jauría; tresillo de legítimo escay [...]. Se creó de este modo un tipo de miseria ornamental, una especie de parodia de lujo burgués que por un lado anunció y 
festejó el final de la lucha de clases y por otro contribuyó decisivamente al auge y divulgación del arte kitsch [...]. Era una carencia profusa, repleta de cachivaches: esto es, de las migajas del gran banquete urbano e industrial" (2004: 131).

En Almodóvar, el kitsch se convierte también en la expresión estética de la frustración de los emigrantes tras haber imaginado un mundo de oportunidades. ¿Qué he hecho yo para merecer esto? (1984) y la familia de Leo en Parla constituyen un tour de force postmoderno de Surcos (Nieves Conde, 1961), donde se desenmascara esta desilusión mediante una estética neorrealista, al estilo de Rocco y sus hermanos (Visconti, 1960). Aunque la manifestación más negra y esperpéntica es la que ofrece Luis García Berlanga en El verdugo (1963), cuyos protagonistas visitan, como actividad lúdica de ocio dominical, las obras del piso que esperan adquirir y fantasean con la distribución del mismo. También Luis Landero (2004: 132) se hace eco de este hábito: “Los domingos [...] nos acercábamos por Alcorcón a ver si había avanzado mucho el piso que alguien (75.000 pesetas de entrada) se había comprado por allí. Durante horas mirábamos los cimientos y comentábamos lo que sería aquello cuando estuviese terminado".

En dichas estampas predomina la visión de la ciudad inhóspita, próxima a la descripción irónica de los arrabales que transmite Luis Martín Santos -“los grandes alcázares de la miseria”- en Tiempo de silencio. “...barriadas, suburbios, rancherías de chabolas, cortijadas residenciales, metrópoli de la colza, corte de la especulación inmobiliaria, ombligo del mundo y villorrio de la humillación y la miseria" (Landero, 2004: 133). Los personajes almodovarianos de la trilogía rural enlazan con estos cinturones urbanos que albergaron a los desplazados y que ponen así en el tapete el papel del espacio periférico como elemento narrativo.

Las huellas de rusticidad no siempre son portadoras de valores diáfanamente positivos, a veces suponen una suerte de marginalidad. La villa almodovariana nunca acaba de ser totalmente una ciudad, sigue siendo un pueblo venido a más donde la nomenclatura de sus calles recuerda su naturaleza ancestral de "poblachón manchego", como la denominó Larra. En Mujeres al borde de un ataque de nervios, Pepa vive en Montalbán, 7 (¿alusión a La Puebla de Montalbán?); y Lucía, en Almagro, 38. En Almagro se filmarán las partes rurales de La flor de mi secreto (1995) y de Volver (2006). 
Chus Lampreave ha sabido encarnar como nadie esta fusión de desequilibrios. En su cuerpo se combinan la tradición de la ropa negra y la modernidad o ruralidad del lenguaje ("Paso total de vosotras", "Te has quedao como vaca sin cencerro"). "Hemos crecido entre palabras que las abuelas trajeron del campo e incrustaron en las paredes del salón" (Del Molino, 2016: 245). Estos personajes de la abuela manchega forzada a vivir en la ciudad se han convertido en iconos de la lucha por conservar las huellas rurales que sobreviven en el barrio: las ramas secas -reliquias con las que ahuyentar el frío-, el lagarto Dinero, o los pimientos asados... Su resistencia numantina vencerá en forma de regreso, y ratificará su triunfo llevándose a alguien de la familia (su nieto Toni, o su hija Leo) para protegerlo de la urbe demoledora de humanidades.

No por eso hay que pensar que el pueblo ha de ser mejor que la ciudad, escenas como la final de ¿Qué he hecho yo para merecer esto? o las del cementerio y el velatorio de Volver muestran bien que la vida en el pueblo se fundamenta demasiado en el culto a la muerte. Y si algo caracteriza al cineasta es el vitalismo. Por eso cuando esta figura es encarnada por la misma Dña. Francisca ya no se trata de personajes de luto en la ciudad, sino un retrato más acabado e insólito de esa penetración de lo rústico en la villa como presentadora del telediario, periodista literaria o comparsa que baila.

El bastidor urbano donde Almodóvar ha urdido este personalísimo tejido ha sido Madrid. La villa tuvo su mejor cronista decimonónico en Galdós, otro provinciano apasionado de la urbe hasta el punto de canibalizarla literariamente a la manera en que Balzac intentó aprehender Paris. Ramón Gómez de la Serna la recreó con exquisita imaginación en deliciosos textos como El Rastro (1931) o Descubrimiento de Madrid (1974). "Una ciudad, un paisaje..., una tierra no está del todo acabada hasta que los pintores o los escritores la colonizan imaginariamente" (Landero, 2002: 133). En cine, la capital ha hallado en Pedro Almodóvar el primer director que va a identificarse absolutamente con ella. El lazo es tan fuerte que no deja de recordar a la Barcelona de Marsé, la Roma de Fellini o a la Nueva York de Woody Allen. Con incursiones rústicas o periféricas, Madrid es el constante decorado, llegando a constituir un verdadero leitmotiv narrativo-descriptivo, un trasfondo recurrente en relatos que se convierten en odas a la capital, como las canciones de Joaquín 
Sabina, quien al igual que el director -y que los personajes de Surcos- emprendió también el recorrido desde un pueblo del sur.

Este Madrid personalísimo, continuamente reinventado, es a veces reflejado en planos oníricos como el fondo de los créditos iniciales de Entre tinieblas (1984), o la ciudad solitaria que apaga sus luces mientras Pepa busca a Iván por calle O’Donell, imagen muy parecida a la angustiosa visión de Abre los ojos (Amenábar, 1997). Y a veces es transformado en decorados como las vistas desde el ático de Pepa en Mujeres... Se trata de una reelaboración continua, una visión multiforme de una ciudad mutante. La metrópoli se humaniza adquiriendo una dimensión claramente metonímica del propio director, quien no intenta reflejar los cambios sufridos por la villa, sino los que va teniendo en su percepción de ella. Cada película supone la actualización de un nuevo Madrid descubierto, como si nunca acabase de asimilarlo.

Con sus hallazgos ha ido tejido un tapiz poliédrico e inacabable como el de Penélope: el Madrid nocturno y agobiante de La ley del deseo (1987), la estación de Atocha y sus circunstancias en Kika (1993); el Chueca de Átame (1990); la Castellana como espina dorsal de Mujeres...(1988); el Callao y la Plaza Real de La flor...(1995); el viaducto en Matador (1986) y Los amantes pasajeros (2013), y la calle Fernando VI en Julieta (2016). Incluso con una incursión histórica en Carne trémula (1997), donde la ciudad adquiere un protagonismo más complejo al reconstruir las Navidades de 1970. La relación con "la ciudad más divertida del mundo" ha madurado y no para de madurar, haciéndose cada vez más profunda y afianzada.

Quizá por ese devenir la ciudad no deja de representar una especie de lugar de tránsito, un salón de espera donde el ser está continuamente desestabilizado. Ejemplo de lo cual es Julieta (2016) y los largos paseos de la protagonista por las zonas de Las Salesas, Justicia y Alonso Martínez. Gracias al carácter de aldea con que es tratada la ciudad, se hace posible el azar, la casualidad, el encuentro fortuito a la vuelta de la esquina. Madrid se constituye en un auténtico sistema en el cual los personajes están siempre en una íntima y doble relación: entre ellos mismos y con la metrópoli. La ciudad se ofrece como un organismo vivo al que el director le ha puesto ese elemento rural que siente en sí mismo, aunque no se vea.

Almodóvar ha hecho de esa sutileza un marchamo expresivo e innovador. Sin duda en su narrativa hay una levedad que llama a los orígenes, que invoca viejas mitologías y que aspira a jugar con ellas o a recrearlas desde la contemporaneidad. Es difícil diseccionar emociones tan íntimas o discursos tan 
volcados hacia el interior. En definitiva, son muchas las forma de volver y todas escarbando en lo perdido con magdalenas evocadoras. Lo interesante es esta recreación sofisticada de un patrimonio insoslayable, la construcción de identidades originales desde la ciudad con una mirada a los mitos heredados que se reelaboran y reinventan con una libertad enorme.

\section{Conclusiones.}

La literatura ha acabado siendo una reparación de daños.

Luis Landero (2002: 14).

Hemos visto que gran parte de obra de Landero y Almodóvar se articula en torno a dos ejes cuyos polos serían el campo y la ciudad. El primer eje estaría constituido por el traslado desde el mundo rural al urbano, y tiene como motor la atracción ejercida por la ciudad: la fascinación por el progreso y la fuerza centrípeta que profesaban el gozo de disfrutar de la modernidad. El segundo eje, a modo de quiasmo artístico, lo formaría el regreso desde la ciudad al campo. Regreso ficticio, no material, cuya fuerza impulsora sería un desquite proustiano a través del cine y la escritura. En este viaje emprendido para reconocer y recuperar elementos de la cultura tradicional y de la infancia dentro de una estética postmodernista, se cifra gran parte de sus tareas como creadores.

Lo urbano y lo rural funcionan como subsistemas con sus propias lógicas en parte del cine y la narrativa actuales, pero la geografía almodovariana trasciende y subsume esta mera yuxtaposición convirtiéndose en una suerte de simbiosis. Lo cual constituiría un reflejo narrativo de algo que, según Sergio del Molino, caracteriza nuestra idiosincrasia: "Se levanta como una niebla leve o como un aroma que sólo perciben unos pocos hiperestésicos olfativos. Pero está. Persiste. Permanece. La España vacía, vacía sin remedio, imposible ya de llenar, se ha vuelto presencia en la España urbana" (Del Molino, 2016: 257).

Ello es posible porque esa España perdida no es sólo un territorio, sino un estado mental que vive en los mitos domésticos y que la literatura y el cine se encargan de propagar. Sus autores han cartografiado una nación hecha de recuerdos, a veces distorsionados, para mantenerlos vivos y legarlos. La tierra abandonada es sólo un referente disperso en los hijos y nietos de quienes la 
habitaron y fueron arrancados de sus solares, pero en el cine de Almodóvar se ha hecho carne y habita entre nosotros en forma de palabras que nadie usa pero que recitadas por Chus Lampreave adquieren el poder de una epifanía o una invocación. Y en la narrativa de Landero se halla en estado latente bajo el tema del afán, el deseo de avance del emigrado que ha idealizado previamente la urbe en la que se asienta, aspecto estructurador de su obra sobre el que vuelve recurrentemente (Martínez Serrano, 2013: 109). El afán se materializa en el personaje del padre, transmisor de este prurito de superación personal: "En mis novelas, de una u otra manera, ese tema vuelve a salir. Me pongo a escribir y cuando me doy cuenta mi padre ya está convertido en personaje" (Landero, 2002: 104).

Por tanto, en ambos la dicotomía campo/ciudad se ha fusionado configurando una genuina sociología con los genes transmitidos por sus creadores, porque todo lo que está en la personalidad corre el riesgo de ser proyectado. Almodóvar o Landero siempre serán los provincianos que viven en la ciudad que les fascinó a finales de los sesenta y que nunca terminarán de diseccionar.

En este cometido y en sus formas de abordarlo mediante una estética a caballo ente dos siglos y dos milenios, han ido modelando un espejo que se pasea entre nosotros devolviéndonos nuestra imagen, enfrentándonos a nuestras raíces y removiéndolas.

Dicho espejo constituye un tema recurrente en ambos autores, pero ¿se podría ir más allá y hablar de un subgénero? Si nos remitimos a la definición de García Berrio y Huerta Calvo (1992: 146) más el criterio histórico-social de Kurt Spang (1996: 36) vemos que la parte analizada cumple los criterios de una forma (narrativa, escrita o visual), un tema recurrente y un contexto histórico-social preciso. Si a ello añadimos el objetivo de recrear un mundo vivido en la infancia distinto al que habitan ahora los autores -escenario desde el que se realiza esta recreación, pero que de alguna forma lo reproduce-, tenemos un componente más de tipo cualitativo: el eje de ida y vuelta del campo a la ciudad y viceversa es "un elemento sistematizador de la referencialidad y un elemento normativizador de la propia sistematización" (Pozuelo 1988: 75).

Este elemento se cumple también con la aparición del kitsch; Almodóvar lo usa en sus comienzos, pero Landero lo teoriza con una reflexión que justifica este empleo: la expresión estética de la frustración de los emigrantes. También se incluiría en este criterio de sistematización el papel de un ancestro femenino como enlace con el mundo perdido: en Landero es su abuela, en Almodóvar, su madre. Por último, la casa 
en ambos en ambos es un espacio clave que sirve para enlazar de alguna forma como microcosmos de la infancia o lugar de afluencias rurales- con los orígenes. Con arreglo a estas premisas teóricas, podríamos hablar de las pautas de un subgénero.

Para ello, tendríamos que analizar sistemáticamente el corpus de las obras narrativas y cinematográficas citadas para ver que responden a esta estructura y reúnen estos componentes. Conscientes de los riesgos que acarrearía esta empresa y de los posibles fallos que hallaríamos en el intento, esperamos sin embargo que el presente estudio haya valido la pena si sirviera para futuros trabajos más acertados en los que se logre captar con mayor alcance y exactitud la repercusión del fenómeno migratorio rural en la narrativa y el cine españoles.

Cabe preguntarse si es un fenómeno peculiar español, o responde a una tendencia generalizada. Es de suponer que cada país haya llevado las tensiones entre el campo y la ciudad a una particular expresión artística según cada idiosincrasia. Los datos demográficos expuestos en el planteamiento sobre la peculiar distribución de la población en España entre el campo y la ciudad, menos homogénea que en otros países europeos, nos hace pensar que esta especial configuración hace del caso español fuente de complejidades propias, algunas de las cuales hemos pretendido esbozar haciendo caso a lo que afirma Sergio del Molino (2016: 29): “Todas las tensiones entre lo urbano y lo rural se han sufrido en España con un dramatismo raro y exótico. Hay toda una literatura inspirada en este Gran Trauma que no tiene igual en Europa. Pero, sobre todo, hay una forma de mirar y de mirarse a sí mismos que es difícil de comprender en otros contextos geográficos”.

Hemos querido analizar dicha forma de mirarse en literatura y en cine para ver en qué consistiría, qué peculiaridades lo definen, y elaborar con ellas las líneas de un subgénero narrativo, pero un fenómeno de este calado difícilmente afectaría sólo a las letras y al séptimo arte, por lógica debería trascender a las restantes manifestaciones artísticas. Entendemos que sería un estudio interesante rastrear sus consecuencias en la música, la pintura, la fotografía, el cómic, etc., de las últimas cuatro décadas para contrastar las ideas apuntadas aquí. 


\section{NOTAS}

[1] Hemos querido empezar con una alusión al nuevo subgénero narrativo que inventó Unamuno (la nívola) para expresar sus ideas filosóficas sobre la identidad por ser un tema que aparece en nuestro estudio.

[2] Llevada al cine en 1987 por Gonzalo Herralde (Laura, del cielo llega la noche), con Ángela Molina como Laura adúltera y el escenario de Vic como modelo de espacio provinciano. Aunque de fecha posterior a las anteriores, la novela de Llor tiene una estructura y un tratamiento del tema que la asimilan al modelo decimonónico.

[3] Disponible en https://www.youtube.com/watch?v=47w_QBDVPDw

[4] Los datos y el mapa mostrados proceden del Instituto Nacional de Estadística y se refieren al 31 de diciembre de 1916.

[5] No sólo en el sentido de la emigración a EEUU. En España coleaba la expresión "hacer las Américas" como recuerdo de los indianos que en su día se enriquecieron en las colonias.

[6] El libro recoge los comentarios del escritor en el programa de TVE Esta es mi tierra: Alburquerque, nostalgia en blanco y negro, emitido el 28 de noviembre de 1999. Disponible en http:/www.rtve.es/alacarta/videos/esta-es-mi-tierra/esta-tierraalburquerque-nostalgia-blanco-negro/668446/. La dicotomía campo/ciudad como condicionante de la obra literaria se analiza en bastantes escritores. Sirvan de ejemplos la Galicia de Luisa Castro o Manuel Rivas, el Tomelloso de García Pavón, o la infancia de Carlos García del Pino en San Roque (Córdoba).

[7] Disponible en: http://www.rtve.es/alacarta/videos/programa/versionespanola-cielo-gira/1399483/

[8] Entrevista Cadena Cope. Ciudad Real, 20 de julio de 1987.

[9] Disponible en: https://www.youtube.com/watch?v=rdAcS6hF-30

[10] El País, suplemento, 7 de abril de 1988.

\section{REFERENCIAS BIBLIOGRÁFICAS}


Libros:

Allinson, M. (2003). Un laberinto español: las películas de Pedro Almodóvar. Madrid: Ocho y Medio.

Aullón de Haro, P. (2016). Idea de la literatura y teoría de los géneros literarios. Salamanca: Ediciones USAL.

Blanco, F. (1989). Pedro Almodóvar. Madrid: Ediciones JC.

Blanco Vila, L. (2013). Literatura y existencia. Ensayo metodológico de Literatura Contemporánea Comparada. Madrid: CEU Ediciones.

Camarero Gómez, G. (2016). Madrid en el cine de Pedro Almodóvar. Madrid: Akal/Cine.

Caparrós Lera, J. Ma . (2005). La Pantalla Popular. El cine español durante el Gobierno de la derecha. (1996-2003). Madrid: Akal.

Celma Valero, M.P. y Ramón González, J. (2010). Lugares de ficción. La construcción del espacio en la narrativa actual. Valladolid: Cátedra Miguel Delibes.

Correa Ulloa, J. D. (2008). Pedro Almodóvar. Alguien del montón. Bogotá: Panamericana Editorial Ltda. 100 Personajes-Autores.

Del Molino, S. (2016). La España vacía. Viaje por un país que nunca fue. Madrid: Turner Noema.

García Berrio, A. y Huerta Calvo, J. (1992) Los géneros literarios: Sistema e Historia. Madrid: Cátedra.

García de León, M. A. y Maldonado, T. (1989). Pedro Almodóvar, la otra España cañí. (Sociología y crítica cinematográficas). Ciudad Real: Ed. Área de Cultura de la Diputación Provincial, Biblioteca de Autores y Temas Manchegos.

Juan Payán, M. (1993). El cine español de los 90. Madrid: Ediciones JC.

Landero, Luis.

- (2001). Entre líneas: el cuento o la vida. Barcelona:

Tusquets, Colección Andanzas.

- (2002). Ésta es mi tierra. Mérida: Editora Regional de Extremadura.

(2004). ¿Cómo le corto el pelo, caballero? Barcelona:

Tusquets, Libros en el Aire. 
(2014). El balcón en invierno. Barcelona: Tusquets, Colección

Andanzas.

Parra, G. (2001). La gran conspiración. El cin e como imagen de nuestro tiempo. Madrid: Celeste Ediciones.

Peña-Ardid, C. (2009). Literatura y cine. Madrid: Cátedra, Signo e Imagen.

Seguin Vergara, J. C. (2009). Pedro Almodóvar o la deriva de los cuerpos. Murcia: Tres Fronteras Ediciones.

Spang, K. (1996). Géneros literarios. Teoría de la literatura y literatura comparada. Madrid: Síntesis.

Strauss, F. (1995). Pedro Almodóvar, un cine visceral. Madrid: El País Aguilar.

Vidal, Nuria. (1988). El cine de Pedro Almodóvar. Madrid: Ministerio de Cultura, ICAA.

Capítulos en libros y volúmenes colectivos:

Landero, L. (2004). Reflexiones sobre mi obra, en Rey Hazas, A. (Dir.). Mostrar con propiedad un desatino. La novela española contemporánea. Madrid: Ediciones Eneida; 99-112.

Landero, L. (2008). El oficio de escritor, en Lomas, C. (Coord.). Textos literarios y contextos escolares. La escuela en la literatura y la literatura en la escuela. Barcelona: Graó, Biblioteca de textos; 221-230.

Martínez Serrano, L. (2013). La dicotomía campo/ciudad en la obra de Luis Landero, en Andrés-Suárez, I. y Rivas, A. (Eds.). Luis Landero. Madrid: Arcolibros; 99-114.

Seguin Vergara, J.C. (2005). El espacio-cuerpo en el cine. Pedro Almodóvar o la modificación, en ZURIÁN, F. y VÁZQUEZ VARELA, C. (Coords.). Almodóvar: el cine como pasión. Actas del Congreso Internacional "Pedro Almodóvar". Cuenca: Ediciones de la Universidad de Castilla-La Mancha; 229-242. 